\title{
Relationships between bacteria, phytoplankton and particulate organic carbon in the Upper St. Lawrence Estuary
}

\author{
Jean Painchaud, Jean-Claude Therriault
}

Institut Maurice-Lamontagne, Ministère des Pêches et des Océans, CP 1000, Mont-Joli, Québec, Canada G5H 3Z4

\begin{abstract}
The relationships between bacterial and phytoplankton variables, and particulate organic carbon (POC), were examined along a longitudinal transect in the St. Lawrence Estuary. Free bacteria, bacterial biomass and heterotrophic activity decreased in a seaward direction, whereas chlorophyll, phytoplankton biomass and photosynthetic activity had minimum values in the mid-estuarine region. Values of POC and attached bacteria were highest at the upper limit of the salinity intrusion, in the zone of maximum turbidity. Free bacteria predominated largely over attached bacteria, which were probably of benthic origin. It is hypothesized that free and attached bacteria formed 2 distincl, independent communities. Correlation analysis showed that, in general, bacterial and phytoplankton variables were highly correlated and that these variables were linked to salinity. The effect of salinity on these correlations was controlled using partial correlation analysis and the results showed that only attached bacteria of the maximum turbidity zone were significantly correlated with chlorophyll and POC concentrations. Elsewhere, phytoplankton and bacterial variables were not correlated. Careful estimation revealed that bacterial biomass largely exceeded that of phytoplankton everywhere, except at the most seaward station, where coastal rather than estuarine conditions prevailed. This study thus suggests that phytoplankton and POC did not to a large extent determine bacterial distribution in the Upper St. Lawrence Estuary and that bacteria may have a relatively important trophic role in this system
\end{abstract}

\section{INTRODUCTION}

Reviewing recent reports of phytoplankton and bacterial abundance and production, Bird \& Kalff (1984) and Cole et al. (1988) found significant correlations between bacterial and phytoplankton variables both in fresh and marine waters, thus suggesting the ubiquity of a functional relationship between bacteria and phytoplankton. Since the latter excrete the organic substrates essential for bacterial metabolism, it can be assumed that bacterial dynamics are essentially controlled by phytoplankton dynamics. This model is probably valid in the oceans, where only sporadic benthic sources (hydrothermal vents, hydrocarbon seepage) produce allochtonous bacterial substrates, and in many lakes. However, in estuaries, the situation is likely to be more complex due to the existence of important sources of non-phytoplanktonic substrates (e.g. vascular plants, benthic macro- and microalgae, inputs from marshes, rivers and Man)

There are estuarine studies suggesting a trophic relationship between bacteria and phytoplankton (e.g.
Coffin \& Sharp 1987, Kirchman \& Hoch 1988). On the other hand, there are also reports that estuarine bacterial and phytoplankton variables are sometimes uncorrelated. For example, no correlation was found between bacterial abundance or heterotrophic activity and chlorophyll concentration or phytoplankton production in a number of small Massachusetts (USA) estuaries (Wright \& Coffin 1983, 1984, Wright et al. 1987), in the Hudson River plume (USA) (Ducklow \& Kirchman 1983), in the Delaware Estuary (USA) (Coffin \& Sharp 1987), and in the Fraser River plume (W Canada) (Albright 1983). Even when significant correlations are found, the problem of autocorrelation should be addressed before concluding that a functional relationship exists between these variables (Legendre \& Troussellier 1988).

Alternatively, particles may be an important factor controlling estuarine bacteria, since extensive bacterial attachment is sometimes observed. Heterotrophic activity and bacterial abundance were largely associated with particulate matter in the Tamar Estuary (SW England) and were highest in the turbidity maximum 
zone (Joint \& Pomroy 1982, Clarke \& Joint 1986, Plummer et al. 1987). In the Humber Estuary (NE England), most bacteria were attached to suspended solids (Goulder 1976, 1977, Bent \& Goulder 1981). Extensive bacterial attachment was also observed in the Fraser River Estuary (Bell \& Albright 1981) and in the Bay of Fundy (E Canada) (Cammen \& Walker 1982).

Considering the potential importance of allochtonous carbon inputs in estuaries, bacterial biomass may be relatively large. Bacterial biomass in the oceans ranges between 10 and $40 \%$ of phytoplankton biomass (Ducklow 1983), but in estuaries it has sometimes been found to equal or exceed that of phytoplankton (Coffin \& Sharp 1987, Delaware Estuary; Wright et al. 1987, Parker Estuary [USA]). Bacterial production exceeded primary production in the turbidity maximum zone of the Delaware Estuary (Kirchman \& Hoch 1988). Therefore, bacteria, both in terms of biomass and carbon flux, might have a greater trophic importance in estuarine than in either freshwater or marine ecosystems.

In this report, we examine the relationships between bacterial and phytoplankton variables (abundance, activity, biomass) as well as with particulate organic carbon (POC) concentrations, in the Upper St. Lawrence Estuary, Canada. Our objectives were: (1) to determine whether the bacteria were mostly attached or free-living and whether their distribution depended on that of either phytoplankton or POC and (2) to determine whether the biomass ratio of bacteria and phytoplankton conformed to that observed in oceanic waters

\section{MATERIALS AND METHODS}

Study area and sampling. Our study area, the Upper St. Lawrence Estuary (Fig. 1) is characterized by a large and relatively steady freshwater discharge of ca $10000 \mathrm{~m}^{3} \mathrm{~s}^{-1}$, reaching a peak of ca $15000 \mathrm{~m}^{3} \mathrm{~s}^{-1}$ in
April-May, and by a 2-layer estuarine circulation. Average tidal amplitude is 3 to $5 \mathrm{~m}$. A well-developped turbidity maximum stretches between lle d'Orléans and Ile aux Coudres; reported suspended particulate matter concentrations vary from 10 to $>200 \mathrm{mg} \mathrm{l}^{-1}$ (Silverberg \& Sundby 1979). Chlorophyll a values and phytoplankton abundance are usually low except at the head of the estuary, near Ile d'Orléans (Cardinal \& Bérard-Therriault 1976, Demers et al. 1979, Lafleur et al. 1979, Painchaud \& Therriault 1985).

Sampling was carried out at 9 stations from 31 July to 6 August 1982 (Fig. 1). At each station, temperature and salinity profiles were measured using a Guildline CTD probe, model 8705 . Biological samples were collected using a cast of 6 Niskin bottles lowered at depths corresponding to 100,30 and $1 \%$ of the surface incident radiation (determined using Secchi disk measurements) and, under the photic zone, at 3 equidistant depths down to a few meters above the bottom.

Sampling of bacteria and biomass estimation. Ten ml subsamples were preserved with glutaraldehyde at a final concentration of $1 \%$ for subsequent counting of bacteria and biovolume estimation. In the laboratory, bacteria were stained with Acridine Orange, filtered onto $25 \mathrm{~mm}, 0.2 \mu \mathrm{m}$ Nuclepore filters and observed with an epifluorescence microscope (Hobbie et al. 1977). Biomass was estimated from biovolume determinations on photographic slides (Ektachrome 400 ASA). Dimensions were obtained from photographs of a calibrated micrometer. Biovolumes were calculated using the formula for the volume of a sphere $\left(4 / 3 \pi r^{3}\right)$ for cocci and the formula for the volume of a cylinder $\left(\pi r^{2} h\right)$ for all other cells. Average biovolumes were estimated at Stns 1, 3, 5, 8 and 9. The total biovolume of a given sample was the product of bacterial abundance and average biovolume estimated at the nearest station. Conversion factors from biovolume to biomass range from $0.1 \mathrm{pg} \mathrm{C} \mathrm{um}^{-3}$ (Zimmerman 1977) to $0.56 \mathrm{pg} \mathrm{C}$ $\mu \mathrm{m}^{-3}$ (Bratbak 1985) with intermediate values of

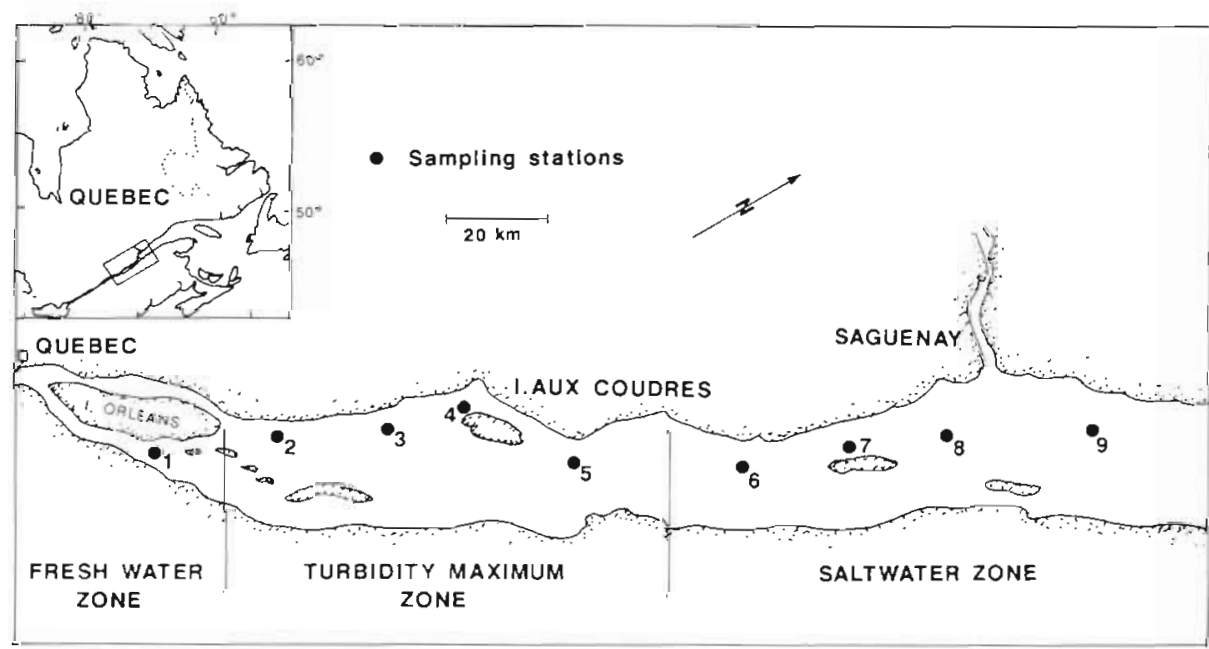

Fig. 1 St. Lawrence Estuary showing station locations. Stippled areas. intertıdal marshes 
$0.12 \mathrm{pg} \mathrm{C} \mu \mathrm{m}^{-3}$ (Watson et al. 1977), $0.2 \mathrm{pg} \mathrm{C} \mu \mathrm{m}^{-3}$

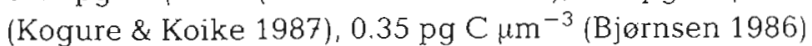
and $0.38 \mathrm{pg} C \mu \mathrm{m}^{-3}$ (Lee \& Fuhrman 1987). A value of $0.3 \mathrm{pg} \mathrm{C} \mu \mathrm{m}^{-3}$ was used in the present study.

Heterotrophic activity. Specific heterotrophic activity was estimated as the maximum rate of uptake $\left(V_{\max }\right)$ of L-glutamic acid (L-[ $\left.{ }^{14} \mathrm{C}(\mathrm{U})\right]$, New England Nuclear, specific activity: 250 to $300 \mathrm{mCi} \mathrm{mmol}^{-1}$ ) divided by bacterial concentration, which yielded the rate of glutamate uptake in $\mathrm{pg}$ cell ${ }^{-1} \mathrm{~h}^{-1}$ (Wright 1978). $\mathrm{V}_{\max }$ was measured using a technique similar to that of Griffiths et al. (1977), whereby only one substrate concentration showing full uptake saturation was utilised. Values of $V_{\max }$ measured this way were equivalent to those resulting from the more material- and timeconsuming technique of Wright \& Hobbie (1966). Care was taken to check regularly that substrate uptake was linear with time and that substrate concentration was saturating. Radioactivity of the samples was measured using a Rack Beta LKB Wallac liquid scintillation counter, model 1215-005. The channel ratio method was used to determine counting efficiency.

POC and phytoplankton determinations. POC was collected on precombusted $25 \mathrm{~mm}$ Whatman GF/C filters that were kept frozen until analysis with a Perkin Elmer Elemental Analyzer, model 240B. Chlorophyll a concentrations were determined using the acetoneextraction fluorometric method of Yentsch \& Menzel (1963). The samples were collected on $25 \mathrm{~mm}$ Whatman GF/C filters and were frozen until analysis using a Turner fluorometer, model 111.

Phytoplankton samples were preserved with formaldehyde (4\% final concentration) and acid Lugol's solution ( $1 \%$ final concentration). The inverted-micioscope method was used to enumerate and identify phytoplankton cells (Hasle 1978). Biomass was calculated from biovolume determinations. As recommended by Smayda (1978), cell plasma volume (PV) was estimated rather than total cell volume. The latter is an inadequate estimate of biomass because it includes the cell vacuole which contains relatively nonnutritious cell sap. PV was calculated as the product of the cell surface area and the parietal cytoplasmic-layer thickness $(1 \mu \mathrm{m})$. For each species, an average PV was estimated and was converted into carbon biomass (pg C cell ${ }^{-1}$ ) using Eq. (10) of Smayda (1978):

$$
\log _{10} \mathrm{C}=0.892\left(\log _{10} \mathrm{PV}\right)-0.61
$$

The total biomass of a given sample was then calculated as the sum of the products of specific biomasses and abundances. Such determinations are labor-intensive and were thus restricted to samples from the photic layer. Details of those calculations as well as information on species composition and cell counts are available in Desilets et al. (1989).
Photosynthetic capacity. Photosynthetic capacity $\left(\mathrm{P}_{\text {max }}^{\mathrm{B}}\right)$ was derived from photosynthesis versus irradiance curves using the photosynthetron method of Lewis \& Smith (1983). A series of $1 \mathrm{ml}$ subsamples were inoculated with $1 \mu \mathrm{Ci} \mathrm{NaH}{ }^{14} \mathrm{CO}_{3}$ and incubated under 18 different light intensities for $20 \mathrm{~min}$. Total $\mathrm{CO}_{2}$ content was estimated for each station using summer carbonate alkalinity values of Pelletier \& Lebel (1979) and conversion factors of Parsons et al. (1984), whose equation was used to convert $\mathrm{dpm}$ incorporated to productivity values $\left(\mathrm{mg} \mathrm{C} \mathrm{m}{ }^{-3} \mathrm{~h}^{-1}\right) . \mathrm{P}^{B}{ }_{\max }$ values were estimated using the model of Platt et al. (1980) and were standardized per unit chlorophyll a. Scintillation counting was done as above. Again, due to the labor involved in these determinations, they were restricted to the photic layer of Stns 1, 3, 4, 5 and 8 .

\section{RESULTS}

\section{Vertical and horizontal distribution}

In surface water, salinity ranged from 0 at Stn 1 to $>20 \%$ in the downstream region of the estuary (Stns 7 to 9 ) and to $>30 \%$ in its deeper part (Fig. 2a). Similarly, temperature decreased from $>20^{\circ} \mathrm{C}$ at $\operatorname{Stn} 1$ to ca $10^{\circ} \mathrm{C}$ in surface waters below $\operatorname{Stn} 4$ and to $<5^{\circ} \mathrm{C}$ at depth (Fig. 2b). Temperature and salinity distributions show that below Stn 2, the estuary was stratified. Chlorophyll a concentrations were larger at both ends of the estuary but were $<1 \mu \mathrm{g} \mathrm{l}^{-1}$ in most of the midestuarine region (Fig. 2c). POC was most abundant at depth at Stn 2, where values up to $1500 \mu \mathrm{g} \mathrm{l^{-1 }}$ were observed; from Stns 3 to 8, values ranged from 100 to $300 \mu \mathrm{g} \mathrm{l}^{-1}$, whereas at both ends of the estuary they exceeded $500 \mathrm{Mg}^{-1}$ (Fig. 2d). Free bacteria decreased from a maximum of ca $2 \times 10^{6}$ cell ml-1 in freshwater to $<0.1 \times 10^{6}$ in the deeper waters of Stns 8 and 9 (Fig. 2e). Free bacteria were more abundant than attached bacteria, except in the bottom layer of Stn 2 (Table 1). Maximum concentrations of attached bacteria were found in the turbidity maximum zone, particularly at Stn 2, and decreased to very low values at downstream stations (Stns 7 to 9 ; Fig. 2f). The percentage of attached bacteria was generally higher in deeper than in surface waters.

The distribution of phytoplankton biomass generally followed that of chlorophyll a with maximum values at both ends of the estuary and lower values $\left(<1 \mu \mathrm{g} \mathrm{Cl}^{-1}\right)$ in most of the mid-estuarine region (Fig. 2g). However, the largest biomass values observed in the surface layer of Stn 9 were 1 order of magnitude greater than surrounding values, which was not paralleled in chlorophyll a distribution. Bacterial biomass gradually decreased from ca $45 \mu \mathrm{g} \mathrm{Cl}^{-1}$ in freshwater to $<5 \mu \mathrm{g} \mathrm{C}$ $1^{-1}$ in the deeper part of Stns 7 to 9 (Fig. 2h). Photo- 


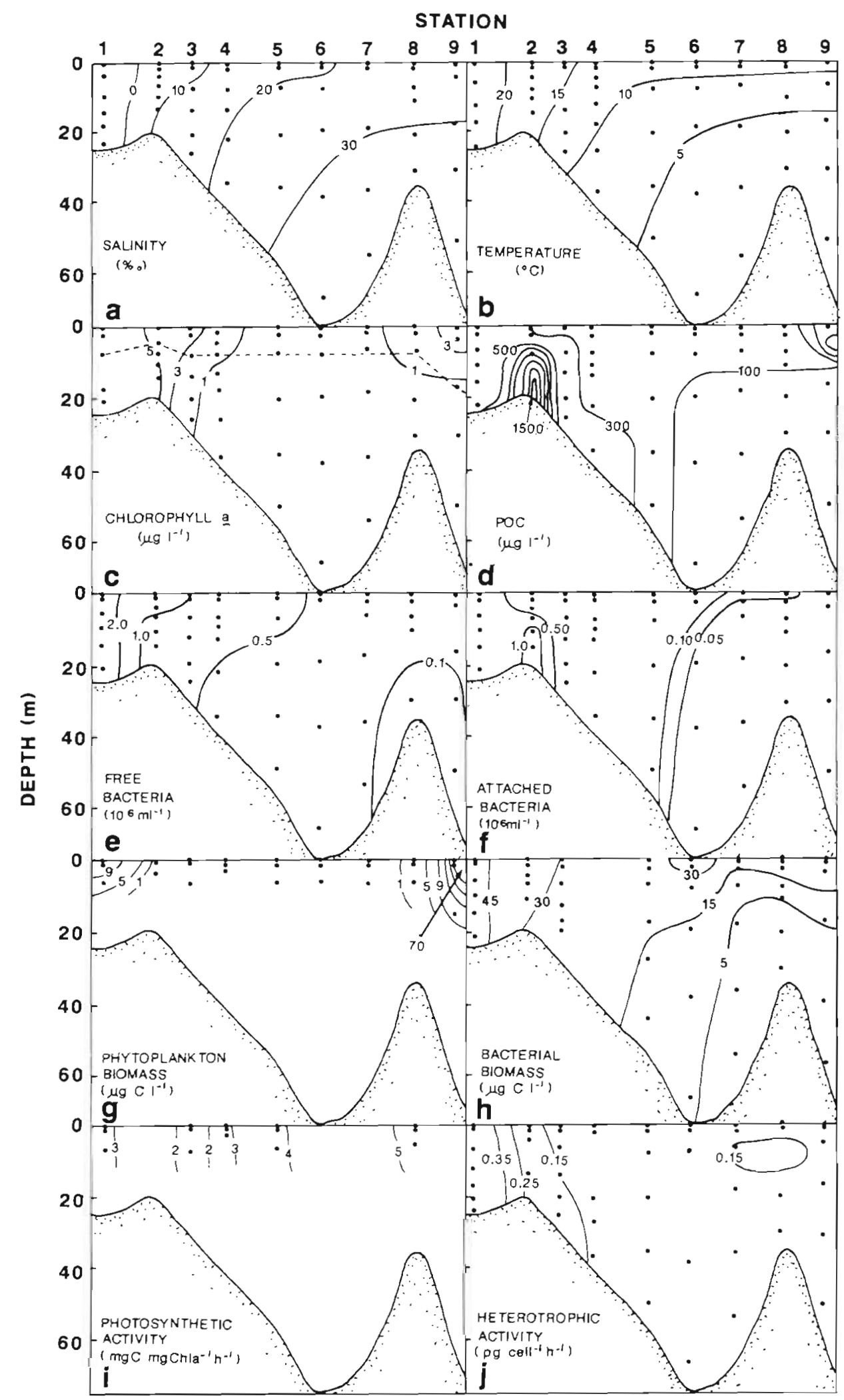

Fig. 2. Longitudinal profiles of (a) salinity, (b) temperature, (c) chlorophyll a, (d) POC, (e) abundance of free bacteria, (f) abundance of attached bacteria, (g) phytoplankton biomass, (h) bacterial biomass, (i) photosynthetic activity and (j) heterotrophic activity 
Table 1. Percentage of attached bacteria (attached/total) in the St. Lawrence Estuary

\begin{tabular}{|c|c|c|c|c|c|c|c|c|c|}
\hline \multirow[t]{2}{*}{ Layer } & \multicolumn{9}{|c|}{ Station } \\
\hline & 1 & 2 & 3 & 4 & 5 & 6 & 7 & 8 & 9 \\
\hline $0-10 \mathrm{~m}$ & 18 & 30 & 29 & 27 & 25 & 24 & 18 & 14 & 0 \\
\hline $10 \mathrm{~m}$ - bottom & 23 & 64 & 43 & 40 & 42 & 17 & 17 & 24 & 4 \\
\hline
\end{tabular}

synthetic activity decreased from ca $5 \mathrm{mg} \mathrm{C} \mathrm{mg} \mathrm{chl}^{-1}$ $\mathrm{h}^{-1}$ at $\operatorname{Stn} 8$ to $<2 \mathrm{mg} \mathrm{C} \mathrm{mg} \mathrm{chl}{ }^{-1} \mathrm{~h}^{-1}$ at Stn 3, where turbidity is greatest, and increased to $\mathrm{ca} 3 \mathrm{mg} \mathrm{C} \mathrm{mg}$ $\mathrm{chl}^{-1} \mathrm{~h}^{-1}$ in freshwater (Fig. 2i). Heterotrophic activity decreased rapidly from $>0.35 \mathrm{pg} \mathrm{cell}{ }^{-1} \mathrm{~h}^{-1}$ in fresh water to $<0.15 \mathrm{pg} \mathrm{cell}{ }^{-1} \mathrm{~h}^{-1}$ below Stn 3 (Fig. 2j). Photic layer averages of phytoplankton and bacterial

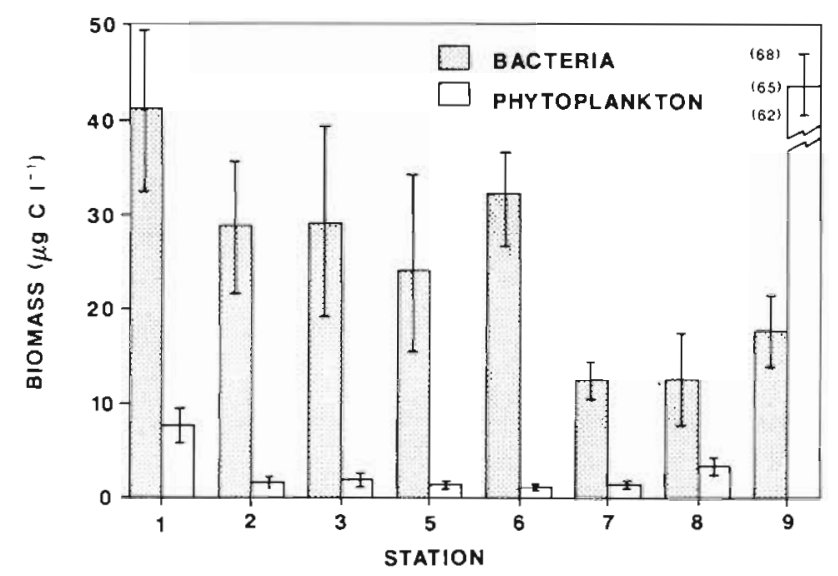

Fig. 3. Comparison of tidally-and depth-averaged bacterial and phytoplankton biomasses in the surface layer of the St. Lawrence Estuary. Bars show range of data

biomasses were calculated and are compared in Fig. 3. Bacterial biomass dominated largely at all stations, except at Stn 9. Phytoplankton biomass was minimum at mid-estuarine stations where turbidity was highest, whereas bacterial biomass was lower downstream, at Stns 7 to 9 . The freshwater station was characterized by relatively larger values of phytoplankton biomass and maximum values of bacterial biomass.

\section{Correlation analysis}

To examine the relationships between bacterial and phytoplankton variables, and POC concentrations, Pearson's correlation coefficients were first calculated on the entire data base (Table 2). Because biological variables did not have normal distributions (Kolmogorov-Smirnov test), they were log-transformed prior to calculations. The analysis reveals significant correlations between all variables, except $\mathrm{P}_{\max }^{\mathrm{max}}$ which was correlated only with chlorophyll concentration. These results suggest that both chlorophyll and POC controlled bacterial variables. However, since all biological variables were correlated with salinity, we suspected that some of the significant correlations between these variables simply resulted from their common relationship with salinity. To test this hypothesis, we reanalyzed the relationships between bacterial variables, chlorophyll and POC concentrations with partial correlation analysis, keeping salinity constant. $\mathrm{P}_{\max }^{\mathrm{B}}$ was excluded from this analysis because of lack of correlation with other variables.

The results (Table 2 , in italics) showed that correlation coefficients dropped to either lower or not significant levels, which suggests that the strong correlations observed between bacterial and phytoplankton variables and POC concentrations were largely due to their respective dependency on salinity. Free bacteria no longer showed a significant relationship with chlorophyll concentration and became negatively correlated with POC. Attached bacteria, however, remained significantly correlated with both chlorophyll and POC. $V_{\max }$ was correlated with chlorophyll and showed an inverse correlation with POC.

The coefficients of partial determination (the square

Table 2. Correlation matrix of salinity and log-transformed biological variables from all stations. In italics (upper right): partial correlation coefficients. $\cdots \mathrm{p} \leq 0.01, \cdot 0.01 \leq \mathrm{p} \leq 0.05 ; \mathrm{n}$ : number of samples

\begin{tabular}{|c|c|c|c|c|c|c|c|}
\hline & $\mathrm{n}$ & Salinity & Chl a & $\mathrm{POC}$ & $\begin{array}{c}\text { Free } \\
\text { bacteria }\end{array}$ & $\begin{array}{l}\text { Attached } \\
\text { bacteria }\end{array}$ & $V_{\max }$ \\
\hline Chl a & 151 & $-0.89^{\cdots}$ & - & & 0.09 & $0.39^{\cdots}$ & $0.17^{\circ}$ \\
\hline $\mathrm{POC}$ & 151 & $-0.69 \cdots$ & $0.76^{\circ}$ & - & $-0.22 \cdots$ & $0.58 \cdots$ & $-0.27 \cdots$ \\
\hline Free bacteria & 151 & $-0.89^{\cdots}$ & $0.81^{\cdots}$ & $0.55^{*}$ & - & & \\
\hline Attached bacteria & 151 & $-0.79^{\cdots}$ & $0.81^{\cdots}$ & $0.80^{*}$ & $0.74^{\cdots}$ & - & \\
\hline$V_{\max }$ & 151 & $-0.57^{\cdots}$ & $0.57^{\cdots}$ & $0.23^{\cdots}$ & $0.54^{\cdots}$ & $0.43^{\cdots}$ & - \\
\hline $\mathrm{P}_{\max }^{\mathrm{B}}$ & 54 & 0.21 & $-0.27^{\circ}$ & -0.26 & -0.18 & -0.23 & 0.13 \\
\hline
\end{tabular}


Table 3. Coefficients of partial determination

\begin{tabular}{|lcccc|}
\hline & $\mathrm{n}$ & Free bacteria & Attached bacteria & $\mathrm{V}_{\max }$ \\
\hline Chl a & 151 & 0.01 & 0.15 & 0.03 \\
POC & 151 & 0.05 & 0.34 & 0.07 \\
\hline
\end{tabular}

of the coefficients of partial correlation; Table 3) were used as a measure of the fraction of the total variance of the bacterial variables explained by their correlation with POC and chlorophyll a (Legendre \& Legendre 1983). They showed that only $5 \%$ of the variance of free bacteria was explained by the correlation with POC. Likewise, small fractions of the variance of $V_{\max }$ were explained by correlations with chlorophyll a $(3 \%)$ and POC $(7 \%)$. On the other hand, the variance of attached bacteria was explained at a higher level by its correlations with chlorophyll a $(15 \%)$ and, mostly, POC $(34 \%)$. Therefore, our results suggest that (1) there is spatio-temporal or functional uncoupling between free bacteria and chlorophyll, (2) the overall links between free bacteria and $V_{\max }$ vs phytoplankton or POC are rather weak, and (3) the distribution of attached bacteria is determined to a significant extent by phytoplankton and POC distributions.

However, an analysis including all data may mask possibly significant and interesting correlations within particular regions of the estuary. From past experience (Painchaud \& Therriault 1985), we felt that our study area could be divided into 3 ecologically distinct zones: freshwater, turbidity maximum and saltwater (Fig. 1).
The same correlation analyses were repeated on data sets from these 3 segments. In the freshwater zone, no significant correlation was found between bacterial variables, chlorophyll and POC concentrations; only the correlation between $\mathrm{V}_{\text {max }}$ and $\mathrm{P}^{\mathrm{B}}$ max was significant and it was based on a very small data set (Table 4a). In the turbidity maximum zone, free and attached bacteria were significantly correlated with chlorophyll a and POC (Table 4b). Partial correlation analysis eliminated any relationship between free bacteria, chlorophyll and POC abundance; attached bacteria, on the other hand, remained significantly correlated with both chlorophyll $a$ and POC (Table 4 b), with high coefficients of determination 10.42 and 0.64 , respectively). Finally, in the saltwater zone, attached bacteria and $V_{\max }$ were not correlated with either POC or chlorophyll a (Table $4 \mathrm{c}$ ). Only free bacteria were correlated with $\mathrm{POC}$ and this correlation was not supported by the partial correlation analysis (Table 4c). These results suggest that bacterial variables were indeed independent of phytoplankton variables or POC abundance except in the zone of maximum turbidity, where organic particle concentration (both phytoplankton and POC) largely determined the abundance of attached bacteria.

\section{DISCUSSION}

\section{Relationships between bacteria and phytoplankton}

Our statistical analyses indicated that bacterial and phytoplankton variables were generally highly corre-

Table 4. Correlation matrix of salinity and log-transformed biological variables from (a) freshwater zone, (b) turbidity maximum zone and (c) saltwater zone. In italics: partial correlation coefficients. ${ }^{p} \leq 0.01, \cdot 0.01 \leq p \leq 0.05 ; n$ : number of samples

\begin{tabular}{|c|c|c|c|c|c|c|c|}
\hline & $\mathrm{n}$ & Salinity & ChI a & POC & Free bacteria & Attached bacteria & $V_{\max }$ \\
\hline \multicolumn{8}{|l|}{ (a) Freshwater zone } \\
\hline POC & 24 & - & 0.30 & - & & & \\
\hline Free bacteria & 24 & - & -0.04 & 0.33 & - & & \\
\hline Attached bacteria & 24 & - & 0.08 & 0.40 & 0.04 & - & \\
\hline $\mathrm{V}_{\max }$ & 24 & - & -0.18 & -0.36 & $-0.54 \cdots$ & 0.05 & - \\
\hline $\mathrm{P}^{\mathrm{E}} \max$ & 9 & - & $-0.79 \cdots$ & 0.39 & -0.53 & -0.05 & $0.65^{\circ}$ \\
\hline \multicolumn{8}{|c|}{ (b) Turbidity maximum zone } \\
\hline Chl a & 84 & $-0.86^{\cdots}$ & - & & 0.09 & $0.65^{\circ}$ & \\
\hline $\mathrm{POC}$ & 84 & $-0.62 \cdots$ & $0.82 \cdots$ & - & -0.07 & $0.80^{\cdots}$ & \\
\hline Free bacteria & 84 & $-0.78 \cdots$ & $0.70^{\cdots}$ & $0.45^{\cdots}$ & - & & \\
\hline Attached bacteria & 84 & $-0.58 \cdots$ & $0.77^{\cdots}$ & $0.87^{\cdots}$ & $0.42 \cdots$ & - & \\
\hline$V_{\max }$ & 84 & -0.21 & $0.24^{\circ}$ & 0.17 & -0.08 & 0.16 & - \\
\hline $\mathrm{P}_{\max }^{\mathrm{B}}$ & 29 & 0.24 & -0.29 & 0.11 & -0.20 & -0.11 & -020 \\
\hline \multicolumn{8}{|l|}{ (c) Saltwater zone } \\
\hline $\mathrm{Chla}$ & 43 & -0.26 & - & & & & \\
\hline POC & 43 & $-0.64 \cdots$ & $0.70^{\cdots}$ & - & 0.29 & & \\
\hline Free bacteria & 43 & $-0.65^{\cdots}$ & 0.26 & $0.59^{\cdots}$ & - & & \\
\hline Attached bacteria & 43 & -0.25 & 0.11 & 0.24 & $0.47 \cdots$ & - & \\
\hline$V_{\max }$ & 43 & 0.18 & 0.11 & -0.06 & $-0.65^{\cdots}$ & $-0.63 \cdots$ & - \\
\hline $\mathrm{P}_{\max }^{\mathrm{E}}$ & 16 & -0.04 & -0.45 & -0.16 & -0.14 & -0.18 & 0.35 \\
\hline
\end{tabular}


lated. However, partial correlation analysis removed the influence of salinity on the correlations between these variables and yielded no evidence of overall relationships between bacterial and phytoplankton variables, thus suggesting that phytoplankton does not determine bacterial distribution in the St. Lawrence Estuary. Alternatively, correlations of bacterial and phytoplanktonic variables with salinity suggest that physical processes (diffusion and advection) were important in determining the distribution of both sets of variables.

In an estuary, the distribution of small biological particles is more or less controlled by physical dispersion processes. In any correlation analysis of estuarine data, biological variables are bound to be internally correlated because of their strong common link to a physical variable such as salinity. Therefore, any interpretation of correlations between biological variables, such as bacterial and phytoplankton abundance, without taking into account their common dependence on salinity is difficult. It leads to ecological interpretations of potentially spurious relationships. This problem has long been recognised in the ecological literature (e.g. Riley 1939). Recently, Legendre \& Troussellier (1988) thoroughly examined the problem of autocorrelation with regard to bacteria-phytoplankton relationships in a brackish lagoon. Their analysis showed how a highly significant correlation between bacteria and phytoplankton could result from a common spatial gradient rather than from functional relationship.

Do our observations mean that bacteria are functionally independent of phytoplankton in our study area? Estuarine phytoplankton production is often limited due to light attenuation by suspended sediment (Cloern 1987). In the St. Lawrence, turbidity up to several hundred $\mathrm{mg} \mathrm{l}^{-1}$ of suspended particulate matter (Silverberg \& Sundby 1979) as well as strong vertical tidal mixing (Demers et al. 1986) put severe constraints on phytoplankton production. Indeed, our data on photosynthetic activity, chlorophyll concentration and phytoplankton biomass suggest rather low phytoplankton productivity. Therefore, phytoplankton is possibly a minor source of carbon for bacteria of the St. Lawrence Estuary and we hypothesize that allochtonous carbon from marshes, sediments, river discharge and sewage provide most bacterial substrates.

Indeed, fluvial inputs are significant, as evidenced by the importance of terrigenous organic material in the sediments of the Upper St. Lawrence Estuary (Pocklington \& Tan 1987). Inputs from marshes and sediments may also contribute dissolved and particulate organic carbon to the water column. Intertidal flats and marshes at the head of the estuary lose large amounts of sediments when the plant cover is destroyed by migratory geese (Lucotte \& d'Anglejan 1986). In Cumberland Basin (Bay of Fundy, Canada), a turbid macrotidal estuary at the same latitude as our study area, salt marshes have also been shown to export significant amounts of carbon to surrounding waters (Gordon et al. 1985). The sediment was the major source of dissolved free amino acids in the water of Kysing Fjord, Denmark (Jørgensen 1982). Leachates from macrophytes (e.g. Spartina spp.) can also contribute significant amounts of dissolved organic matter to the estuary (Turner 1978). All these potentially important sources of carbon are as yet uncharacterized and unquantified in the St. Lawrence, but we suspect that they are significant.

In the freshwater zone of the St. Lawrence Estuary, however, a paradoxical situation is observed: elemental and isotopic composition of organic matter suggests that planktonic production is significant in summer (Pocklington \& Tan 1987). Indeed, chlorophyll concentrations (Painchaud \& Therriault 1985, this study) and phytoplankton abundance (Cardinal \& Bérard-Therriault 1976, Desilets et al. 1989) are high relative to those found in adjacent estuarine waters. However, bacterial biomass was greater than phytoplankton biomass and bacterial and phytoplankton variables seemed uncoupled. This suggests that other important sources of carbon must provide substrates for bacterial growth. Anthropogenic inputs are likely to be a major source of carbon in this section of the estuary. Québec City with a population of ca 600000 is a relatively important urban center and its wastewaters are still untreated. Coliforms, organic and inorganic nitrogen and phosphorus, and chemical oxygen demand have been reported to be high in the section of the St. Lawrence below Québec City relative to other sections of the river away from important urban or industrial centers (Noël \& Simard 1975a, b). Thus, elevated bacterial biomass at Stn 1 probably results largely from anthropogenic inputs. We can speculate that bacterial biomass may decrease and become more dependent on phytoplankton for substrates when the wastewater treatment facilities now under construction are operational.

\section{Importance and dynamics of attached vs free bacteria}

Our observations showed that most bacteria were free-living throughout the estuary and correlation analyses indicated that they were largely independent of POC concentrations, except attached bacteria in the turbidity maximum zone. Contrary to observations by Joint \& Pomroy (1982) in the Severn Estuary (England) and by Clarke \& Joint (1986) and Plummer et al. (1987) 
in the Tamar Estuary, the turbidity maximum zone of the St. Lawrence was not characterized by greater total bacterial abundance or heterotrophic activity. Therefore, our results suggest that attachment is not an essential strategy for bacteria in the St. Lawrence and that POC cannot be regarded as a major controlling factor of bacterial dynamics.

The question of bacterial attachment has received considerable attention in aquatic microbial ecology. The early hypotheses, that natural bacteria had to be associated with particulate matter, have not been supported by the large body of information gained since the advent of epifluorescence microscopy. The possible advantages of attachment are uncertain. Goulder et al. (1981) examined 3 potential advantages: development of greater heterotrophic potential per cell, nutritional advantage because of adsorption of dissolved organic matter, and protection from grazing zooplankton. These authors found none of these hypothetical advantages to be significant. Moreover, even in estuaries characterized by extensive bacterial attachment, free bacteria are often more abundant than attached bacteria (e.g. Tamar Estuary; Clarke \& Joint 1986). These observations and our own results suggest that attachment is not a more essential strategy for estuarine than for freshwater and marine bacteria.

However, we did observe some bacterial attachment at depth and in the turbidity maximum zone where the attached bacteria were correlated with POC concentrations. Considering that the turbidity maximum in the St. Lawrence is produced by the resuspension of bottom sediments at the head of the estuary, combined with density-driven circulation (Silverberg \& Sundby 1979), then attached bacteria must be largely of benthic origin. It is probably because of resuspension of sediments (tide- or wave-generated or through any other mechanism), which is more effective than in lakes, rivers or oceans, that important populations of attached bacteria can be encountered in estuaries. Benthic or attached bacteria often seem correlated with POC or with suspended particulate matter concentrations (Bent \& Goulder 1981, Cammen \& Walker 1982, Clarke \& Joint 1986, this study). These observations suggest that the abundance of attached bacteria in estuaries is largely determined by the processes resuspending particulate material.

Since particles are recirculated several times, attached bacteria probably have long residence times within estuaries. Free bacteria, on the other hand, are largely controlled by dispersive processes (advection and diffusion) and have much shorter residence times. Using the tidal prism method (Dyer 1973), flushing times (T) were calculated in segments defined by station positions. From Stns 1 to 5, T was of the order of 3 tidal cycles from one station to the next below, so exchange ratios $(1 / T)$ were of the order of 0.33 tide $^{-1}$ or ca $0.03 \mathrm{~h}^{-1}$. The abundance of bacteria at any one point of the estuary is determined by a dynamic balance between this exchange ratio and net bacterial growth rate. In this area, growth rates estimated using the seawater culture method of Ducklow \& Hill (1985) varied in the range 0.06 to $0.1 \mathrm{~h}^{-1}$ at $0 \%, 0.05$ to $0.06 \mathrm{~h}^{-1}$ at 0 to $5 \%$ and 0.02 to $0.03 \mathrm{~h}^{-1}$ at $10 \%$ (unpubl.). Losses due to mortality and predation must be subtracted from these estimates to obtain net growth rates. So, except in freshwater, physical exchange ratios are likely to be larger than net growth rates, thus preventing the accumulation of large bacterial populations. This possibly explains the decreasing gradient of abundance of free bacteria from fresh to marine waters. Therefore, the St. Lawrence Estuary can perhaps be considered as an accumulative system for attached bacteria and a dispersive system for free bacteria. It can be hypothesized that free and attached bacteria form 2 distinct and possibly uncoupled populations. Considering that controlling factors, spatio-temporal variations and sources of substrates are likely to differ widely, models of estuarine bacterial dynamics should therefore consider these populations separately.

\section{Phytoplankton vs bacterial biomass}

Our results showed that the biomass of phytoplankton was larger than that of bacteria only at Stn 9. There, bacteria reached ca $25 \%$ of phytoplankton biomass, a ratio in the middle of the 10 to $40 \%$ range reported by Ducklow (1983) for oceanic waters. This station is located in the deeper part of the estuary, a region characterized by coastal rather than truly estuarine processes (Therriault \& Levasseur 1985). At all other stations, bacterial biomass largely exceeded that of phytoplankton. If phytoplankton biomass had been estimated over the entire water column and reported on a surface $\left(\mathrm{m}^{-2}\right)$ rather than volumetric $\left(\mathrm{l}^{-1}\right)$ basis, the dominance of bacteria would have been even larger, because chlorophyll decreased more rapidly with depth than bacterial abundance.

The remarkable point of these observations is not so much that bacterial biomass was large; in fact, it was less than summer values reported recently from other temperate estuaries (Table 5). It is rather that phytoplankton biomass is strikingly low. On average, it represents ca $10 \%$ of bacterial biomass and a few percent of POC, much less than the $55 \%$ of the POC hypothesized by Pocklington \& Tan (1987). It was important for this study to evaluate phytoplankton biomass correctly The usual method of estimating phytoplankton biomass relies on the use of a conversion factor allowing transformation of chlorophyll into car- 
Table 5. Bacterial and phytoplankton biomass from temperate estuaries

\begin{tabular}{|c|c|c|c|c|}
\hline $\begin{array}{l}\text { Bacteria } \\
\left(\mu \mathrm{g} \mathrm{Cl}^{-1}\right)\end{array}$ & $\left(\mu g \mathrm{Cl}^{-1}\right)^{\mathrm{F}}$ & ton $\left(\mu \mathrm{g} \operatorname{chl} a \mathrm{l}^{-1}\right)$ & Estuary & Source \\
\hline $20-70$ & & $5-50$ & Ems-Dollard & Admiraal et al. (1985) \\
\hline 75 & $200-400$ & & Delaware & Coffin \& Sharp (1987) \\
\hline $100-200$ & $150-2000$ & & Parker & Wright et al. (1987) \\
\hline $17-311$ & & $1-6$ & Fraser & Bell \& Albright (1981) \\
\hline $1-50$ & $1-70$ & & St. Lawrence & This study \\
\hline
\end{tabular}

bon. These $\mathrm{C}$ : chl ratios are most often derived from a linear regression of POC on chlorophyll. However, when abundant and variable amounts of detrital carbon are present, as was the case in our samples, this approach can be extremely misleading (see Banse 1977). Moreover, $\mathrm{C}$ : chl ratios vary with and within taxonomic groups (Chan 1980). In the present study, the phytoplankton communities changed very much in abundance and species composition (Desilets et al. 1989) as well as physiological state along the salinity gradient. For these reasons, estimations of phytoplankton biomass with $\mathrm{C}$ : chl ratios could not be utilised and the microscopical method, although tedious, yielded much more reliable results.

Considering the size of bacterial biomass relative to that of phytoplankton, and given the generally low phytoplankton productivity observed in our study area, bacteria may have a relatively greater trophic importance in the Upper St. Lawrence Estuary than in other systems. Therefore, studies of the structure and functions of this ecosystem, particularly food web or carbon flow studies, should include bacteria.

\section{CONCLUSION}

Results show that bacteria are dominant in terms of biomass in the Upper St. Lawrence Estuary. However, our data do not suggest that phytoplankton or POC are major controlling factors of bacterial abundance, although POC is probably important in determining the abundance of attached bacteria, particularly in the turbidity maximum zone. Our study also suggests that estuarine bacteria form 2 distinct populations: freeliving bacteria, independent of POC and of phytoplankton, and attached bacteria, controlled largely by sediment dynamics. Free bacteria are probably fueled by carbon from a variety of sources; it is unlikely that any one of them can be identified as a dominant controlling factor, considering the complexity of these sources. Attached bacteria, on the other hand, might dominate locally in episodes of intense sediment resuspension, such as during wind events. Finally, our study suggests that bacteria may be a relatively more impor- tant component of the structure and functions of this estuarine ecosystem than of other systems.

Acknowledgements. This study was initiated as an Unsolicited Proposal (contract. FP715-2-00814) when J.P. was with Bio-Conseil Inc., where $M$. Gagnon provided significant scientific and administrative support. D. Dubois carried out bacterial counts and biomass estimation. Y. Chagnon and $M$. Gosselin assisted in collecting the data. We thank S. Demers, $\mathrm{J}$. Gearing and anonymous reviewers for constructive comments on our manuscript.

\section{LITERATURE CITED}

Admiraal, W., Beukema, J., Van Es, F. B. (1985). Seasonal fluctuations in the biomass and metabolic activity of bacterioplankton and phytoplankton in a well-mixed estuary: the Ems-Dollard (Wadden Sea). J. Plankton Res. 7: $877-890$

Albright, L. J. (1983). Influence of river-ocean plumes upon bacterioplankton production of the Strait of Georgia, B.C. Mar. Ecol. Prog. Ser. 12: 107-113

Banse, K. (1977). Determining the carbon-to-chlorophyll ratio of natural phytoplankton. Mar Biol. 41. 199-212

Bell, C. R., Albright, L. J. (1981). Attached and free-floating bacteria in the Fraser River estuary, British Columbia, Canada. Mar Ecol. Prog. Ser. 6: 317-327

Bent, E. J., Goulder, R. (1981). Planktonic bacteria in the Humber Estuary: seasonal variation in population density and heterotrophic activity. Mar. Biol. 62: 35-45

Bird, D. F., Kalff, J. (1984). Empirical relationships between bacterial abundance and chlorophyll concentration in fresh and marine waters. Can. J. Fish. Aquat. Sci. 41: 1015-1023

Bjørnsen, P. K. (1986). Automatic determination of bacterioplankton biomass by image analysis. Appl. environ. Microbiol. 51: 1199-1204

Bratbak, G. (1985). Bacterial biovolume and biomass estimations. Appl. environ. Microbiol. 49: 1488-1493

Cammen, L. M., Walker, J. A. (1982). Distribution and activity of attached and free-living suspended bacteria in the Bay of Fundy. Can. J. Fish. Aquat. Sci. 39: 1655-1663

Cardinal, A., Bérard-Therriault, L. (1976). Le phytoplancton de l'estuaire moyen du Saint Laurent en amont de l'Ileaux-Coudres (Québec). Int. Rev. ges. Hydrobiol. 61: $639-648$

Chan, A. T. (1980). Comparative physiological study of marine diatoms and dinoflagellates in relation to irradiance and cell size. I1. Relationship between photosynthesis, growth, and carbon-to-chlorophyll a ratio. J. Phycol. 16: 428-432 
Clarke, K. R., Joint, I. R. (1986). Methodology for estimating numbers of free-living and attached bacteria in estuarine waters. Appl. environ. Microbiol. 51. 1110-1120

Cloern, J. E. (1987). Turbidity as a control on phytoplankton biomass and productivities in estuaries. Cont. Shelf Res. 7 : $1367-1381$

Coffin, R. B., Sharp, J. H. (1987). Microbial trophodynamics in the Delaware Estuary. Mar. Ecol. Prog. Ser. 41: 253-266

Cole, J. J., Findlay, S., Pace, M. L. (1988). Bacterial production in fresh and saltwater: a cross-system overview. Mar. Ecol. Prog. Ser. 43: 1-10

Demers, S., Lafleur, P. E., Legendre, L., Trump, C. L. (1979) Short-term covariability of chlorophyll and temperature in the St. Lawrence Estuary. J. Fish. Res. Bd Can. 36: 568-573

Demers, S., Legendre, L., Therriault, J.-C. (1986). Phytoplankton responses to vertical tidal mixing. In: Bowman, J., Yentsch, M., Peterson, W. T. (eds.) Tidal mixing and plankton dynamics. Lecture Notes on Coastal and Estuarine Studies, Vol 17. Springer-Verlag, Berlin, p.1-40

Desilets, H., Painchaud, J., Therriault, J.-C. (1989). Abondance, composition spécifique et biomasse du phytoplancton de l'estuaire moyen du Saint-Laurent. Rapp. tech. can. sci. halieut. aquat. 1698

Ducklow, H. W. (1983). Production and fate of bacteria in the oceans. BioScience 33: 494-501

Ducklow, H. W., Kirchman, D. L. (1983). Bacterial dynamics and distribution during a spring diatom bloom in the Hudson River plume, USA. J. Plankton Res. 5: 333-356

Ducklow, H. W., Hill, S. M. (1985). The growth of heterotrophic bacteria in the surface waters of warm core rings. Limnol. Oceanogr. 30: 239-259

Dyer, K. R. (1973). Estuaries: a physical introduction. Wiley \& Sons, London

Gordon, D. C., Cranford, P. J., Desplanque, C. (1985) Observations on the ecological importance of salt marshes in the Cumberland Basin, a macrotidal estuary in the Bay of Fundy. Estuar. coast. Shelf Sci. 20: 205-227

Goulder, R. (1976). Relationships between suspended solids and standing crops and activities of bacteria in an estuary during a neap-spring-neap tidal cycle. Oecologia (Berl.) 24: $83-90$

Goulder, R. (1977). Attached and free bacteria in an estuary with abundant suspended solids. J. appl. Bacteriol. 43: $399-405$

Goulder, R., Bent, E. J., Boak, A. C. (1981). Attachment to suspended solids as a strategy of estuarine bacteria. In: Jones, N. V., Wolff, W. J. (eds.) Feeding and survival strategies of estuarine organisms. Plenum Press, New York, p.1-15

Griffiths, R. P., Hayasaka, S. S., McNamara, T. M., Morita, R. I. (1977). Comparison between two methods of assaying relative microbial activity in marine environment. Appl. environ. Microbiol. 34: 801-805

Hasle, G. R. (1978). The inverted-microscope method. In: Soumia, A. (ed.) Phytoplankton manual. Monographs on oceanographic methodology \#6. UNESCO, Paris, p. 88-96

Hobbie, J. E., Daley, R. J., Jasper, S. (1977). Use of Nuclepore filters for counting bacteria by epifluorescencce microscopy. Appl. environ. Microbiol. 33: 1225-1228

Joint, I. R., Pomroy, A. J. (1982). Aspects of microbial heterotrophic production in a highly turbid estuary. J. exp. mar. Biol. Ecol. 58: 33-46

Jorgensen, N. O. G. (1982). Heterotrophic assimilation and occurrence of dissolved free amino acids in a shallow estuary. Mar. Ecol. Prog. Ser 8: 145-159

Kirchman, D. L., Hoch, M. P. (1988). Bacterial production in the Delaware Bay Estuary estimated from thymidine and leucine incorporation rates. Mar. Ecol. Prog. Ser. 45: 169-178

Kogure, K., Koike, I. (1987). Particle counter determination of bacterial biomass in seawater Appl. environ. Microbiol. 53: $274-277$

Lafleur, P. E., Legendre, L., Cardinal, A. (1979). Dynamique d'une population estuarienne de diatomées planctoniques: effet de l'alternance des marées de morte-eau et de viveeau. Oceanologica Acta 2: 307-315

Lee, S., Fuhrnan, J. A. (1987). Relationships between biovolume and biomass of naturally derived marine bacterioplankton. Appl. environ. Microbiol. 53: 1298-1303

Legendre, L., Legendre, P. (1983). Numerical ecology, developments in environmental modelling, 3. Elsevier, Amsterdam

Legendre, P., Troussellier, M. (1988). Aquatic heterotrophic bacteria: modeling in the presence of spatial autocorrelation. Limnol. Oceanogr. 33: 1055-1067

Lewis, M. R., Smith, J. C. (1983). A small volume, shortincubation-time method for measurement of photosynthesis as a function of incident irrradiance. Mar. Ecol. Prog. Ser. 13: 99-102

Lucotte, M. d'Anglejan, B. (1986). Seasonal control of the Saint-Lawrence maximum turbidity zone by tidal-flat sedimentation. Estuaries 9: 84-94

Noël, J.-G., Simard, R.E. (1975a). Niveau de pollution du fleuve Saint-Laurent de Repentigny Montmagny, I. Pollution microbienne. Naturaliste can. 102: 199-208

Noël, J.-G., Simard, R. E. (1975b). Niveau de pollution du fleuve Saint-Laurent de Repentigny Montmagny, II. Pollution biochimique. Naturaliste can. 102: 209-218

Painchaud, J., Therriault, J.-C. (1985). Heterotrophic potential in the St. Lawrence Estuary: distribution and controlling factors. Naturaliste can. 112: 65-76

Parsons, T. R., Takahashi, M., Hargrave, B. (1984). Biological oceanographic processes. 3rd edn. Pergamon Press, New York

Pelletier, E., Lebel, J. (1979). Hydrochemistry of dissolved inorganic carbon in the St. Lawrence Estuary (Canada). Estuar. coast. Shelf Sci. 9: 785-795

Platt, T., Gallegos, C. L., Harrison, W G. (1980). Photoinhibition of photosynthesis in natural assemblages of marine phytoplankton. J. mar. Res. 38: 687-701

Pocklington, R., Tan, F. C. (1987). Seasonal and annual variations in the organic matter contributed by the St. Lawrence River to the Gulf of St. Lawrence. Geochim. Cosmochim. Acta 51: 2579-2586

Plummer, D. H., Owens, N. J. P., Herbert, R. A. (1987). Bacteria-particle interactions in turbid estuarine environments. Cont. Shelf Res. 7: 1429-1433

Riley, G. A. (1939). Correlations in aquatic ecology with an example of their application to problems of plankton productivity. J. mar. Res. 2: 56-73

Silverberg, N., Sundby, B. (1979). Observations in the turbidity maximum of the St. Lawrence Estuary. Can. J. Earth Sci. 16: $939-950$

Smayda, T J. (1978). From phytoplankters to biomass In: Soumia, A. (ed.) Phytoplankton manual. Monographs on oceanographic methodology \#6. UNESCO, Paris, p. $273-279$

Therriault, J.-C., Levasseur, M. (1985). Control of phytoplankton production in the lower St. Lawrence Estuary: Light and freshwater runoff. Naturaliste can. 112: 77-96

Turner, R. E. (1978). Community plankton respiration in a salt marsh estuary and the importance of macrophytic leachates. Limnol. Oceanogr. 23: 442-451 
Watson, S. W., Novitsky, T J., Quinby, H. L., Valois, F. W (1977). Determination of bacterial number and biomass in the marine environment. Appl environ. Microbiol. 33: 940-946

Wright, R. T (1978). Measurement and significance of specific activity in the heterotrophic bacteria of natural waters. Appl. environ. Microbiol. 36: 297-305

Wright, R. T., Coffin, R. B. (1983). Planktonic bacteria in estuaries and coastal waters of northern Massachusetts: spatial and temporal distribution. Mar. Ecol. Prog. Ser. 11 205-216

Wright, R. T., Coffin, R. B. \{1984\}. Factors affecting bacterioplankton density and productivity in salt marsh estuaries. In: Klug, M. J., Reddy, C. A. (eds.) Current perspectives in microbial ecology. Proc. 3rd Int. Symp. Microb. Ecol., Michigan State Univ, 7-12 Aug 1983. Am. Soc. Microbiol.,

This article was submitted to the editor
Washington, D. C., p. 485-494

Wright, R. T., Coffin, R. B., Lebo, M. E. (1987). Dynamics of planktonic bacteria and heterotrophic microflagellates in the Parker Estuary, northern Massachusetts. Cont. Shelf Res. 7: 1383-1397

Wright, R. T., Hobbie, J. E. (1966). Use of glucose and acetate by bacteria and algae in aquatic ecosystems. Ecology 47 : $447-464$

Yentsch, C. S., Menzel, D. W (1963). A method for the determination of phytoplankton, chlorophyll and pheophytin by fluorescence. Deep Sea Res. 10: 221-231

Zimmermann, R. (1977). Estimation of bacterial number and biomass by epifluorescence microscopy and scanning electron microscopy. In: Rheinheimer, G. (ed.) Microbial ecology of a brackish water environment, Vol. 25. Springer-Verlag, New York, p. 104-120

Manuscript first received: January 4, 1989 Revised version accepted: May 29, 1989 